\title{
International Accounting Standard 7 - Statement of Cash flows - Compared to the Lebanese General Accounting Plan
}

\author{
Maysam Ayoub ${ }^{1}$, Weam Jammoul ${ }^{2}$, Selim Mekdessi ${ }^{3}$ \\ ${ }^{I}$ Maysam Ayoub, CPA, MBA, Lebanon \\ ${ }^{2}$ Weam Jammoul, certified accountant and professor, Lebanon \\ ${ }^{3}$ Selim Mekdessi, Ph.D., Full Professor, Faculty of Economic Sciences and Business Administration, Lebanese \\ University, Lebanon.
}

\begin{abstract}
The purpose of this study is to challenge the differences between the statement of cash flows based on the Lebanese general accounting plan and the statement of cash flows as per IAS 7. The study is not limited to IAS 7 (IFRS) but includes ASC 230 (US GAAP) and the French general accounting plan as well. When comparing the statement of cash flows in accordance with ASC 230 and French general accounting plan with the statement of cash flows in accordance with IAS 7 requirements, it is concluded that the differences in classifying cash flows, components of cash and cash equivalents and the format of the statement are insignificant and, eventually, does not affect comparability. However, the comparability of Lebanese general accounting plan with IAS 7, ASC 230 and the French general accounting plan regarding the statement of cash flows is difficult due to the differences in classification of cash flows, components of cash and cash equivalents and the format of the statement. In addition, the theoretical part is supported by a questionnaire that was addressed to auditors in Lebanon. Hence, it is recommended to replace the current statement of cash flows with the recognized format as per IAS 7. In addition, upcoming research should focus more on the statement of cash flows in Lebanon so that reporting is in line with international standards.
\end{abstract}

Keywords: IAS 7, US GAAP, Statement of Cash Flows, General Accounting Plan, Operating activities, Financing activities, Investing activities

\section{Introduction}

The financial aspects of business transactions and events of an entity are reflected in its financial statements. S. Carraher, and H. Van Auken (2013) state that "financial statements allow stakeholders to use available financial information to gain a better understanding of and manage their firm" [1]. As a matter of fact, the use of financial statements contributes to achieving the strategic goals of an entity because solid decisions are taken when the financial aspect is considered.

The basic financial statements are the statement of financial position (also known as the balance sheet), income statement (also known as the profit and loss statement), the statement of changes in equity (also known as the statement of retained earnings) and the statement of cash flows. First, the balance sheet gives an overview of the entity at a specific point in time as if it was standing still [2]. Second, "the income statement reflects the results of operations during an accounting period" [3]. As for the statement of changes in equity, it displays the movement in shareholders' equity over an accounting period. Finally, the statement of cash flows, derived from the balance sheet and income statement, measures the cash inflows and outflows for a period of time in order to determine the ability of the entity to generate cash and cash equivalents and the needs of the entity to use these cash flows [4]. This highlights the significance of the statement of cash flow because it aids "users of financial information who are interested in predicting, comparing and evaluating potential cash flows in terms of amount, timing and uncertainty" as per Abu-Abbass, and Al-Abdullah (2012) [5].

The comparability of financial statements across entities will be affected by the high degree of heterogeneity; and ultimately, the high degree of non-compliance with IASB standards may create the risk of misleading the users of financial information [6]. Therefore, the need for internationally recognized and accepted standards is needed as financial markets are becoming more interdependent in order to achieve consistency and comparability in financial reporting worldwide especially when financial information are originating from different countries using different accounting standards [7]. "Thus, there has arisen the urgent need for promulgation of a common set of global accounting standards or global convergence into a common language of accounting, the language of business, for the financial world. International Financial Reporting Standards (IFRS), the standards promulgated by the International Accounting Standards Board (IASB), previously known 4as International Accounting Standards (IASs) that was issued by International Accounting Standard Committee (IASC), the IASB's predecessor body, appear to be emerging the global accounting standards and according to some, could even qualify for the coveted title of "the Esperanto of accounting" [7]. There are several financial statements that aid us in assessing the financial health of an entity, but the statement 
of cash flow is the most important because it reflects the liquidity of the entity [8]. Therefore, the statement of cash flows helps analysts in assessing whether the entity may encounter financial difficulties [9]. Accordingly, an entity shall prepare a statement of cash flows, as an integral part of its financial statements, in compliance with IAS 7.

In their paper "Auditing the Statement of Cash Flows for Jordanian Public Listed Companies", Eman Hanini and Modar Abdullatif found out that auditors of Jordanian public listed companies recognize the importance of the statement of cash flows and cover the operating, investing and financing activities in their audit. In addition, they analyze the statement of cash flows using ratio analysis in order to evaluate the entity's going concern hypothesis. However, the level of perceived significance and the use of audit procedures was reported as being relatively limited, an issue that raises doubts over the quality of such audits and the awareness of auditors as to the importance of auditing the statement of cash flows. Hence, previous studies emphasize the need to tackle the statement of cash flows in developing countries such as Lebanon.

\section{A- Statement of cash flow defined based on IAS 7}

\section{Research Field And Methodology}

\section{Purpose of the statement of cash flows}

The statement of cash flows explains how a company's cash was generated during the period and how the cash was used. It does not replace the income statement; the two statements have different purposes. The income statement measures the results of operations for a period of time, while the statement of cash flows provides details about the changes in cash and cash equivalents during the period. Thus, the statement of cash flows reports the period's transactions and events in terms of their impact on cash [10].

The statement of cash flows, as its name suggests, includes only actual inflows and outflows of cash and cash equivalents only; accordingly, it excludes all transactions that do not directly affect cash receipts and payments [11]. The reason for excluding noncash transactions in the statement of cash flows and placing them within disclosures keeps the statement's primary focus on cash flows from operating, investing, and financing activities in the original state so that users of financial statements can fully understand the importance of what this financial statement does [11].

IAS 7 mentions examples of non-cash transaction:

1. "the acquisition of assets either by assuming directly related liabilities or by means of a finance lease;

2. the acquisition of an entity by means of an equity issue; and

3 . the conversion of debt to equity"

\section{Results of the statement of cash flows}

The increase or decrease in cash and cash equivalents is the end result of the statement of cash flows. As per IAS 7, "Cash and cash equivalents comprise cash on hand and demand deposits, together with shortterm, highly liquid investments that are readily convertible to a known amount of cash, and that are subject to an insignificant risk of changes in value. Guidance notes indicate that an investment normally meets the definition of a cash equivalent when it has a maturity of three months or less from the date of acquisition. Equity investments are normally excluded, unless they are in substance a cash equivalent (e.g. preferred shares acquired within three months of their specified redemption date). Bank overdrafts which are repayable on demand and which form an integral part of an entity's cash management are also included as a component of cash and cash equivalents".

\section{Presentation of the statement of cash flows}

IAS states that "An entity presents its cash flows from operating, investing and financing activities in a manner which is most suitable to its business. Classification by activity provides information that allows users to assess the impact of those activities on the financial position of the entity and the amount of its cash and cash equivalents. This information may also be used to evaluate the relationships among those activities. A single transaction may include cash flows that are classified differently. For example, when the cash repayment of a loan includes both interest and capital, the interest element may be classified as an operating activity and the capital element is classified as a financing activity".

\section{Operating activities}

Operating activities are those main revenue-generating activities of the entity. Operating activities, the main revenue-generating activities of an entity, result from the transactions and other events that enter in to the determination of profit or loss which makes those activities revenue generating [12]. IAS 7 states that "the amount of cash flows arising from operating activities is a key indicator of the extent to which the operations of the entity have generated sufficient cash flows to repay loans, maintain the operating capability of the entity, pay dividends and make new investments without recourse to external sources of financing. Information about the 
specific components of historical operating cash flows is useful, in conjunction with other information, in forecasting future operating cash flows".

IAS 7 mentions examples of transaction that should be part of operating activities:

1. "cash receipts from the sale of goods and the rendering of services;

2. cash receipts from royalties, fees, commissions and other revenue;

3. cash payments to suppliers for goods and services;

4. cash payments to and on behalf of employees;

5. cash receipts and cash payments of an insurance entity for premiums and claims, annuities and other policy benefits;

6. cash payments or refunds of income taxes unless they can be specifically identified with financing and investing activities; and

7. cash receipts and payments from contracts held for dealing or trading purposes.

Investing activities

According to IAS 7, "the separate disclosure of cash flows arising from investing activities is important because the cash flows represent the extent to which expenditures have been made for resources intended to generate future income and cash flows. Only expenditures that result in a recognised asset in the statement of financial position are eligible for classification as investing activities".

IAS 7 mentions examples of transaction that should be part of investing activities:

1. cash payments to acquire property, plant and equipment, intangibles and other long-term assets. These payments include those relating to capitalised development costs and self-constructed property, plant and equipment;

2. cash receipts from sales of property, plant and equipment, intangibles and other long-term assets;

3. cash payments to acquire equity or debt instruments of other entities and interests in joint ventures (other than payments for those instruments considered to be cash equivalents or those held for dealing or trading purposes);

4. cash receipts from sales of equity or debt instruments of other entities and interests in joint ventures (other than receipts for those instruments considered to be cash equivalents and those held for dealing or trading purposes);

5. cash advances and loans made to other parties (other than advances and loans made by a financial institution);

6. cash receipts from the repayment of advances and loans made to other parties (other than advances and loans of a financial institution);

7. cash payments for futures contracts, forward contracts, option contracts and swap contracts except when the contracts are held for dealing or trading purposes, or the payments are classified as financing activities; and

8. cash receipts from futures contracts, forward contracts, option contracts and swap contracts except when the contracts are held for dealing or trading purposes, or the receipts are classified as financing activities.

Financing activities

According to IAS 7, "the separate disclosure of cash flows arising from financing activities is important because it is useful in predicting claims on future cash flows by providers of capital to the entity"

1. IAS 7 mentions examples of transaction that should be part of financing activities:

2. cash proceeds from issuing shares or other equity instruments;

3. cash payments to owners to acquire or redeem the entity's shares;

4. cash proceeds from issuing debentures, loans, notes, bonds, mortgages and other short or long-term borrowings;

5. cash repayments of amounts borrowed; and

6. cash payments by a lessee for the reduction of the outstanding liability relating to a finance lease.

Reporting cash flows

According to IAS 7, an entity shall report cash flows from operating activities using either the direct method, whereby major classes of gross cash receipts and gross cash payments are disclosed; orthe indirect method, whereby profit or loss is adjusted for the effects of transactions of a non-cash nature, any deferrals or accruals of past or future operating cash receipts or payments, and items of income or expense associated with investing or financing cash flows. However, entities are encouraged to report cash flows from operating activities using the direct method rather than the indirect method.

This is supported by previous studies. For example, Koji Kojima and 児島幸治 concluded in their paper titled "Decision Usefulness of Cash Flow Information Format" that more accurate decisions can be made by using the direct method rather than the indirect method while presenting the cash flows from operating 
activities [13]. In addition, A study prepared by Jeffrey Hales and Steven F. Orpurt titled "Review of Academic Research on the Reporting of Cash Flow from operations" suggests that information derived from the direct method are economically significant such that costs exceed benefits [14].

\section{B- IAS 7 (Under IFRS) compared to ASC 230 (Under US GAAP)}

Cash and cash equivalents

1- When defining cash and cash equivalents, IAS 7 and ASC 230 include cash and short-term, highly liquid investments having a maturity of three months or less. However, IAS 7 states that bank overdrafts are also included as a component of cash and cash equivalents. On the contrary, ASC 230 states that "restricted cash and restricted cash equivalents are not an element of cash and cash equivalents in the statement of cash flows" so that restricted cash is generally presented within investing activities.

2- ASC 230 states that "the total amounts of cash and cash equivalents at the beginning and end of the period shown in the statement of cash flows shall be the same amounts as similarly titled line items or subtotals shown in the statements of financial position as of those dates". IAS 7, on the other hand, states that "the components of cash and cash equivalents should be disclosed, and a reconciliation presented to amounts reported in the statement of financial position".

3- Both ASC 230 and IAS 7 require entities to disclose their policies in determining cash and cash equivalents. However, IAS 7 states that "the components of cash and cash equivalents should be disclosed, and a reconciliation presented to amounts reported in the statement of financial position".

Classification of Components of Transactions in the Statement of Cash Flows

When cash outflows and inflow involves more than one type of activity, according to ASC 230, " the appropriate classification shall depend on the activity that is likely to be the predominant source of cash flows for the item". On the other hand, an entity should "classify each individual component in a transaction separately as either operating, investing, or financing" as per IAS 7.

Reporting cash flows from operating activities

ASC 230 and IAS 7 allow the use of direct or indirect method for reporting cash flows from operating activities. Accordingly, IAS 7 indicates that the entity reconciles net income to net cash flows from operating activities only when using the indirect method. However, ASC 230 states that a reconciliation "shall be provided regardless of whether the direct or indirect method of reporting net cash flow from operating activities is used".

Other differences:

Analysts should be aware of the differences in the cash flows statement prepared in accordance with IFRS and U.S. GAAP. As a matter of fact, the IASB allows more flexibility in the reporting of items. For example:

U.S. GAAP classifies interest and dividends received from investments as operating activities, whereas IFRS allows companies to classify those items as either operating or investing cash flows [15].

U.S. GAAP classifies interest expense as an operating activity, even though the principal amount of the debt issued is classified as a financing activity. On the other hand, IFRS allows companies to classify interest expense as either an operating activity or a financing activity [15].

U.S. GAAP classifies dividends paid to stockholders as a financing activity. However, IFRS allows companies to classify dividends paid as either an operating activity or a financing activity [15].

U.S. GAAP classifies all income tax expenses as an operating activity. IFRS also classifies income tax expense as an operating activity, unless the tax expense can be specifically identified with an investing or financing activity (e.g., the tax effect of the sale of a discontinued operation could be classified under investing activities) [15].

\section{C- IAS 7 (Under IFRS) compared to the French general accounting plan}

The French general accounting plan classifies cash flows in the cash flows statement as the classifications mentioned in IAS 7 and U.S. GAAP in to operating, investing and financing activities. Similar to IAS 7 and US GAAP, the direct method and indirect method for reporting cash flows from operating activities are allowed.

IAS 7 states that "Cash balances and cash equivalents held by a subsidiary working in a country having exchange control or other legal restrictions are included in cash and cash equivalents. That amount must be disclosed in notes if it is of such significant that requires disclosing, with a management comment on this". However, the French text excluded them from the elements of cash in addition to disclosures. The French general accounting plan classifies dividends paid to stockholders as a financing activity. However, IFRS allows companies to classify dividends paid as either an operating activity or a financing activity. The French general accounting plan classifies dividends received from investments as operating activities, whereas IFRS allows companies to classify those items as either operating or investing cash flows. 


\section{D- IAS 7 (Under IFRS),ASC 230 (Under US GAAP) and French General Accounting Plan}

Regarding the components of cash and cash equivalents, IAS7, ASC 230 and French general accounting plan include cash and short-term, highly liquid investments having a maturity of three months or less are included in cash equivalents. However, slight differences were noted such as bank overdraft, restricted cash and cash equivalents held by a subsidiary working in a country having exchange control or other legal restrictions. Regarding the presentation of the statement of cash flows, all recognized statements report the changes in cash and cash equivalents as a result of operating, investing and financing activities. Concerning the format of the statement, all allow the direct and indirect method in reporting cash flows from operating activities, but direct is encouraged.

Therefore, the difference between the three statements are insignificant and do not affect comparability. Lebanese general accounting plan compared to IAS 7, U.S. GAAP and French general accounting plan Unlike IAS 7, ASC 230 and French general accounting plan, the statement of cash flows adopted by the Lebanese general accounting plan involves a fourth category, listed under cash flows from operating activities, called cash flows from working capital.

Changes in accounts payable as a result of acquisition of fixed assets are included in cash flows from working capital within operating activities. This will cause cash flows from operating activities and investing activities to be misleading.

Regarding charges to be allocated to more than one period, the Lebanese general accounting plan states that the changes in these balances should be included with cash flows from working capital. However, the French general accounting plan treats these charges as long term assets.

The two accounts "periodic distribution of expenses" and "periodic distribution of revenues" were considered in the working capital elements in the Lebanese cash flows statement. These two accounts are temporary accounts and do not cause any cash flow.

Re-evaluating differences is considered in the Lebanese cash flows statement from financing activities and their effects on assets from cash flows used in investment activities. As a result of increase in the market value of certain assets over time, revaluation is necessary. According to IAS 7, "Investing and financing transactions which do not require the use of cash shall be excluded from the statement of cash flow, but they should be separately disclosed elsewhere in the financial statements". On the other hand, revaluation is included in the statement of cash flows adopted in accordance with the Lebanese general accounting plan. Moreover, Statement of Financial Accounting Standards No. 95 issued by Financial Accounting Standards Board clearly states that "The Board agreed that excluding noncash transactions from the statement of cash flows would better achieve the statement's objective without resulting in implementation difficulties. This Statement thus requires that information about noncash investing and financing transactions be reported in related disclosures. If there are only a few such transactions, it may be convenient to include them on the same page as the statement of cash flows. Otherwise, the transactions may be reported elsewhere in the financial statements, clearly referenced to the statement of cash flows".

The statement of cash flows as per the Lebanese general accounting plan considers:

1. changes in reserves and retained earnings from the elements of financing cash flows;

2. changes in accounts payable resulting from buying investment securities is considered cash flows from financing activities

3. investment securities and financial institutions accounts are included within cash and cash equivalents

\section{Methodology}

The target population consisted ofauditors in Lebanon. A computer generated random list of 100 auditors in Lebanon who ultimately have knowledge and understanding of the cash flow statement. This list served as the sampling frame. To account for the impact of the low response rate, surveys were shared online and in hand. The final realized sample included a total 77 respondents, representing a $77 \%$ response rate. All 77 surveys were analyzed. The survey was designed according to the objectives of the study so that its results can be used practically and academically in modifying the content of the statement of cash flows in Lebanon to meet the requirements of IAS 7 if necessary.

Table 1 provides a demographic profile of the respondents who participated in the study. The sample was dominant by Accounting major auditors (85.7\%) and licensed CPAs (61\%). In addition, auditors having less than 5 years of experience represented $6.5 \%$ of the respondents. These results contributed to reliable results due to the major and professional experience of the respondents. Regarding education, the lowest portion pertains to a doctorate degree $10.4 \%$ which is reasonable due to faculty shortages in the Accounting field in Lebanon. 
Table 1: Demographic profile of respondents

\begin{tabular}{|c|c|c|}
\hline & $\mathbf{N}$ & $\%$ \\
\hline \multicolumn{3}{|l|}{ Major: } \\
\hline Accounting & 66 & 85.7 \\
\hline Business Administration & 2 & 2.6 \\
\hline Economics & 0 & 0 \\
\hline Banking and Finance & 9 & 11.7 \\
\hline Total & 77 & 100 \\
\hline \multicolumn{3}{|l|}{ Educational: } \\
\hline Bachelor & 37 & 48.1 \\
\hline Master & 32 & 41.6 \\
\hline Doctorate & 8 & 10.4 \\
\hline Total & 77 & 100 \\
\hline \multicolumn{3}{|c|}{ Years of experience in accounting and auditing: } \\
\hline less than 5 years & 5 & 6.5 \\
\hline 5 to 10 years & 26 & 33.8 \\
\hline 10 years to 15 years & 33 & 42.9 \\
\hline more than 15 years & 13 & 16.9 \\
\hline Total & 77 & 100 \\
\hline \multicolumn{3}{|l|}{ Certifications: } \\
\hline $\mathrm{CPA}$ & 47 & 61 \\
\hline CMA & 8 & 10.4 \\
\hline CIA & 0 & 0 \\
\hline Other & 0 & 0 \\
\hline No professional certificate & 22 & 28.6 \\
\hline Total & 77 & 100 \\
\hline
\end{tabular}

\section{Validity and Reliability}

The validity and reliability of the information collected have a profound consequence on the quality of the research conducted. Reliability is the extent to which an assessment tool generates consistent and stable results. First, the study established reliability by designing a questionnaire based on Likert scales ranging from "Strongly Disagree" on one end to "Strongly Agree" on the other with "Neither Agree nor Disagree" in the middle. Furthermore, this research showed consistency with the literature review and it demonstrated agreements with other present researches and studies in the field of accounting and auditing. Third, reliability was confirmed by Cronbach's Alpha coefficient of 0.725 which is within an acceptable range.

Validity refers to how well a test measures what it is supposed to measure which was maintained through sampling validity. Auditors provide services to a wide variety of clients that include individual taxpayers, government agencies, large businesses, non-profits and educational institutions. The services performed by public accountants generally fall within three categories Accounting and auditing services, tax services and consulting services. Hence, the auditors represent the most appropriate sample of a population selected.

\section{Results}

Through analyzing the data of the research the researcher reached the following results:

1. The Lebanese cash flows statement does not comply with the basic requirements of IAS 7: Statement of Cash Flows

2. The Lebanese cash flows statement does not agree with any recognized format such as the French general accounting plan or US GAAP.

3. The line items used in the statement of cash flows do not agree with the line items used in the balance sheet and income statement.

4. The statement of flows in Lebanon adopted in Lebanon is more likely a sources and uses of funds statement.

5. In contrast to statement of cash flows presented in accordance with IAS 7 or any recognized statement, the statement of cash flows adopted in Lebanon includes an additional category called cash flows from working capital, as part of operating cash flows

6. Accounts payable resulting from the acquisition of fixed assets should be considered as investing activities rather than operating activities. Failure to report cash flows related to the acquisition of fixed assets properly will cause cash flows that arise from normal operations such as revenues and cash operating expenses (operating cash flows) and cash flow that arises from investment activities such as the acquisition or disposition of current and fixed assets (investing cash flows) to be misleading. 
7. The cash flows statement adopted in Lebanon considers prepaid expenses and deferred revenues from the elements of working capital while these two accounts are temporary accounts and it is not correct to include them in the working capital elements.

8. Short term financing and long term financing are presented in the same line item in the statement of cash flows adopted in Lebanon

9. Acquisition of tangible and intangible assets are presented in the same line item in the statement of cash flows adopted in Lebanon

10. Investment securities are included within cash and cash equivalents in the statement of cash flows adopted in Lebanon

11. In the statement of cash flows adopted in Lebanon, balances with financial institutions are included within cash and cash equivalents unlike other statements of cash flows accepted by other recognized statement of cash flows

12. Although an entity shall prepare a statement of cash flow in accordance with the requirements of IAS 7, it is not mandatory in Lebanon to publish it.

13. Accounting disclosures to the financial statements are not separated from the declared figures to the tax authorities.

14. Entities in Lebanon are required to statement of cash flows using the direct method.

15. In Lebanon, statement of cash flows is not treated as a significant financial statement on the academic and professional level.

\section{Conclusion}

As part of testing the hypothesis according to the auditors' input in the survey, the mean and standard deviation of the auditor's specialization, related educational qualification and years of experience were analyzed. It was concluded that the general direction of auditor was a "strongly agree" to the hypothesis regardless of specialization, related educational experience, and years of experience.

A comparison between the statement of cash flows based on the Lebanese general accounting plan versus statement of cash flows in compliance with IAS 7 was challenged through a theoretical framework and a quantitative survey distributed to a sample of auditors in Lebanon. When comparing the statement of cash flows in accordance with U.S. GAAP and French general accounting plan to the statement of cash flows in accordance with IAS 7 requirements, no significant differences were noted. On the other hand, when comparing the statement of cash flows based on the Lebanese general accounting plan to IAS 7, statement of cash flows, U.S. GAAP and French general accounting plan, critical differences were identified which affect comparability. Therefore, based on our theoretical framework, the Lebanese cash flows statement does not comply with IAS 7 requirements and any other recognized statement of cash flows (e.g. U.S. GAAP, French general accounting plan). This was also supported by the quantitative survey which validated the theoretical aspect.

\section{Proposed Recommendations:}

1. Adopt IAS 7 in the preparation of cash flows statement by companies in Lebanon.

2. Include the presentation of statement of cash flows in Lebanon while covering all its aspects in future researches and studies

3. Provide training courses and seminars in order to emphasize the significance of the statement of cash flows and to raise the importance of abiding by international standards in terms of comparability in specific.

4. Amend the terminology used in the statement of cash flows to agree with the line items used in the balance sheet and income statement.

5. Analyze the investment and financing transactions during the period to know the actual cash flows rather than depending on the change in balances.

6. Publishing the statement of cash flows should not be optional.

7. Reporting financial statements for accounting purposes should be separated from the declaration presented to the tax authorities by providing specific requirements for each.

8. Companies should have the option to choose between the direct and indirect method in presenting their statement of cash flows.

9. More attention should be paid to the statement of cash flows in academia.

10. Payables that arise from the acquisition of fixed assets should be included in the investing activities in the statement of cash flows.

11. Cash flows related to the acquisition of tangible fixed assets should be separated from the cash flows related to the acquisition of intangible assets.

12. Cash flows related to medium loans should be separated from cash flows related to long-term loans. 


\section{References}

[1]. S. Carraher, and H. Van Auken, The use of financial statements for decision making by small firms, Journal of Small Business \& Entrepreneurship, 26(3), 2013, 323-336.

[2]. G. Fried, S.J. Shapiro, and T.D. DeSchriver, Sport finance (Champaign, IL: Human Kinetics, 2008).

[3]. R. L.Weil, K. Schipper, and J. Francis, Financial accounting: an introduction to concepts, methods and uses (Cengage Learning, 2013)

[4]. P. M. Rao, Financial Statement Analysis and Reporting (New Delhi, PHI Learning Private Limited,2011).

[5]. B. Abu-Abbass, and R. Al-Abdullah, The domination of the pure form of capitalism over the objectives of financial statements (reporting),Journal of Accounting and Taxation, 4(3), 2012, 44.

[6]. R. Pekdemir, and N. K. YÖNET, Exploratory Evidence for the Adoption of the IAS 7 in Turkey, Accounting and Management Information Systems, 9(4), 2010, 524.

[7]. A. A. Mirza, M. Orrell, and G. Holt, Wiley IFRS: practical implementation guide and workbook (Hoboken,NJ: John Wiley \& Sons ,2010).

[8]. T. R. Dyckman, R. E. Dukes, and C. J. Davis, Intermediate accounting (Vol. 2) (Richard d Irwin, 1998)

[9]. F. J. Fabozzi and P.P. Peterson, Financial management and analysis (Vol. 132) (Hoboken,NJ: John Wiley \& Sons, 2003).

[10]. W. Albrecht, J. Stice, E. Stice, and M. Swain, Accounting: concepts and applications (Cengage Learning, 2007)

[11]. Epstein, B. J., \& Jermakowicz, E. K. WILEY Interpretation and Application of International Financial Reporting Standards (Hoboken,NJ: John Wiley \& Sons, 2010)

[12]. W.A. Grier, Credit analysis of financial institutions. (Euromoney Books, 2007)

[13]. K. Kojima, and 治.児島幸, Decision usefulness of cash flow information format: An experimental study, International review of business, (12), 2012, 23-44.

[14]. J. Hales, and S. F. Orpurt, A review of academic research on the reporting of cash flows from operations, Accounting Horizons, 27(3), 2013, 539-578

[15]. T. Robinson, H. van Greuning, E. Henry, and M.A. Broihahn, International financial statement analysis (Vol. 22). (Hoboken,NJ: John Wiley \& Sons, 2008) 